See Article page 1015

\section{Commentary: Why do coronary artery bypass grafting transfusion rates vary? We still don't know}

\author{
Alison F. Ward, MD, and Richard Lee, MD, JD, MBA
}

Multiple studies have shown that in patients undergoing isolated coronary artery bypass grafting $(\mathrm{CABG})$, red blood cell (RBC) transfusions are associated with increased postoperative costs, morbidity, and mortality. ${ }^{1-4}$ Although society guidelines exist, they do not provide specific transfusion triggers, and there remains wide variation in rates of RBC transfusion across institutions, regions, and physicians. ${ }^{5-7}$ In this issue of the Journal, Fitzgerald and colleagues $^{8}$ aim to identify to what extent patient and procedural characteristics may help explain institution-level variation in RBC transfusion rates in patients undergoing CABG. Unfortunately, they fell short of being able to explain this variation by patient and procedural characteristics alone.

Our first concern with this study is the limited sample size of 22,000 patients who underwent isolated CABG over 6 years and 43 institutions. In comparison, the Society of Thoracic Surgeons (STS) database has data on more than 150,000 patients who underwent isolated CABG from 2018 alone, which adds up to close to 900,000 patients over the same time period. By using variables from the STS database instead of merging records from the PERForm and STS databases, would an explanation for institutional-level variation in RBC transfusions become clearer?

The authors analyzed patient demographics, laboratory values, risk factors, and procedural variables in an effort to explain the variability in $\mathrm{RBC}$ transfusions across

\footnotetext{
From the Division of Cardiothoracic Surgery, Department of Surgery, Medical College of Georgia, Augusta University, Augusta, Ga.

Disclosures: The authors reported no conflicts of interest.

The Journal policy requires editors and reviewers to disclose conflicts of interest and to decline handling or reviewing manuscripts for which they may have a conflict of interest. The editors and reviewers of this article have no conflicts of interest.

Received for publication May 20, 2020; revisions received May 20, 2020; accepted for publication May 20, 2020; available ahead of print May 25, 2020.

Address for reprints: Richard Lee, MD, JD, MBA, Department of Surgery, Medical College of Georgia, 1120 15th St, BA-4300, Augusta, GA 30912 (E-mail: richardleemdmba@gmail.com or RICKLEE@augusta.edu).

J Thorac Cardiovasc Surg 2022;163:1028-9

$0022-5223 / \$ 36.00$

Copyright (c) 2020 by The American Association for Thoracic Surgery

https://doi.org/10.1016/j.jtcvs.2020.05.035
}

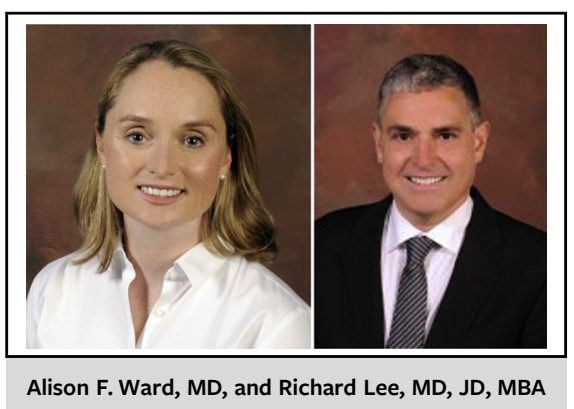

\begin{abstract}
CENTRAL MESSAGE
The authors show that patient and procedural factors don't explain interhospital variability of transfusions in CABG patients; is that due to a flawed study design or true interhospital variability?
\end{abstract}

hospitals. Although potentially limited by the data from these databases, there are critical variables that are notably absent. Clinically relevant values that cardiac surgeons routinely assess, like preoperative RBC transfusions, pretransfusion hematocrit, and chest-tube output, were absent. To discuss intraoperative and postoperative RBC transfusions without any data on preoperative transfusion is incomplete, especially since more than $65 \%$ of the patients transfused in this study were urgent or emergent admission status, ie, they are likely inpatients with that data available. Pretransfusion hematocrit is of particular interest because it acts as a surrogate value for RBC transfusion triggers. Without knowing each institutional and individual threshold for RBC transfusion, a pretransfusion hematocrit would allow us to see how widely these values vary. And, finally, data on chest-tube output would differentiate RBC transfusions for postoperative bleeding versus anemia.

Despite the rigorous statistical analysis in this manuscript, we are still no closer to understanding the essential question here-why is there such interhospital variability in $\mathrm{RBC}$ transfusion rates in patients who undergo CABG? In our opinion this is 2-fold-either this study did not comprehensively capture patient and procedural characteristics that could explain the variability or the variability is in fact not due to patient and procedural characteristics but rather a lack of consensus in RBC transfusion triggers in the cardiothoracic community. Society guidelines provide recommendations, but they lack specific thresholds for $\mathrm{RBC}$ transfusion in the perioperative and postoperative 
settings. Ultimately, further studies with a larger sample size and more clinically relevant variables, in addition to looking across institutions and regions with robust blood conservation protocols, will be needed to determine what is the cause of interinstitutional RBC transfusion variability and how to limit that variability.

\section{References}

1. Koch CG, Li L, Duncan AI, Mihaljevic T, Cosgrove DM, Loop FD, et al. Morbidity and mortality risk associated with red blood cell and bloodcomponent transfusion in isolated coronary artery bypass grafting. Crit Care Med. 2006;34:1608-16.

2. LaPar DJ, Crosby IK, Ailawadi G, Ad N, Choi E, Spiess BD, et al. Blood product conservation is associated with improved outcomes and reduced costs after cardiac surgery. J Thorac Cardiovasc Surg. 2013;145:796-803; discussion 803-4.

3. Paone G, Likosky DS, Brewer R, Theurer PF, Bell GF, Cogan CM, et al. Transfusion of 1 and 2 units of red blood cells is associated with increased morbidity and mortality. Ann Thorac Surg. 2014;97:87-93; discussion 93-4.

4. Shehata N, Naglie G, Alghamdi AA, Callum J, Mazer CD, Hebert P, et al. Risk factors for red cell transfusion in adults undergoing coronary artery bypass surgery: a systematic review. Vox Sang. 2007;93:1-11.

5. Pagano D, Milojevic M, Meesters MI, Benedetto U, Bolliger D, von Heymann C, et al. 2017 EACTS/EACTA guidelines on patient blood management for adult cardiac surgery. Eur J Cardiothorac Surg. 2018;53:79-111.

6. Society of Thoracic Surgeons Blood Conservation Guideline Task Force, Ferraris VA Brown JR, Despotis GJ, Hammon JW, Reece TB, et al. 2011 update to the Society of Thoracic Surgeons and the Society of Cardiovascular Anesthesiologists blood conservation clinical practice guidelines. Ann Thorac Surg. 2011;91:944-82.

7. Likosky DS, Al-Attar PM, Malenka DJ, Furnary AP, Lehr EJ, Paone G, et al. Geographic variability in potentially discretionary red blood cell transfusions after coronary artery bypass graft surgery. J Thorac Cardiovasc Surg. 2014;148: 3084-9.

8. Fitzgerald DC, Simpson AN, Baker RA, Wu X, Zhang M, Thompson MP, et al Determinants of hospital variability in perioperative red blood cell transfusions during coronary artery bypass graft surgery. J Thorac Cardiovasc Surg. 2022; 163:1015-24.e1. 